\title{
PERJANJIAN DENGAN JAMINAN FIDUSIA BERDASARKAN PERATURAN MENTERI KEUANGAN REPUBLIK INDONESIA NOMOR 130/PMK.010/2012
}

\author{
HARNIWATI \\ Sekolah Tinggi Ilmu Hukum Padang \\ harniwati@gmail.com
}

Abstract: The provision of fiduciary guarantees in banking transactions generally uses a notarial deed and has been clearly regulated, but how about the implementation of the fiduciary guarantee. Implementation of the Agreement with Fiduciary Guarantee Based on the Regulation of the Minister of Finance of the Republic of Indonesia Number 130/Pmk.010/2012". The research method used in this research is mainly library research by examining secondary data, sourced from primary, secondary and research legal materials. This is done to obtain the necessary accurate data related to the problem under study. The registration of fiduciary guarantees has been determined by the Fiduciary Guarantee Law Number 42 of 1999, which is also confirmed in the Regulation of the Minister of Finance of the Republic of Indonesia Number 130/PMK.010/2012.

Keywords: Agreement, Guarantee, Fiduciary, Permenkeu.

\begin{abstract}
Abstrak: Pemberian jaminan fidusia dalam transaksi perbankan pada umumnya menggunakan akta notaris dan telah diatur dengan jelas, namun bagaimanakah mengenai pelaksanaan pemberian jaminan fidusia itu. Pelaksanaan Perjanjian Dengan Jaminan Fidusia Berdasarkan Peraturan Menteri Keuangan Republik Indonesia Nomor 130/Pmk.010/2012". Metode penelitian yang digunakan dalam penelitian ini terutama adalah Penelitian kepustakaan dengan mengkaji data sekunder, yang bersumber dari bahan hukum primer, sekunder dan Penelitian. Hal ini dilakukan untuk mendapatkan data akurat yang diperlukan berkaitan dengan masalah yang diteliti. Pendaftaran jaminan fidusia telah ditentukan oleh Undang-undang Jaminan Fidusia Nomor 42 Tahun 1999, yang juga ditegaskan dalam Peraturan Menteri Menteri Keuangan Republik Indonesia Nomor 130/PMK.010/2012.
\end{abstract}

Kata Kunci: Perjanjian, Jaminan, Fiducia, Permenkeu.

\section{A. Pendahuluan}

Dalam rangka pembinaan hukum nasional, bidang hukum yang meminta perhatian serius antara lain ialah bidang hukum jaminan. Jaminan ini berkaitan erat dengan perkembangan kebutuhan akan kredit dan keamanan bagi pemberi fasilitas kredit tersebut (Sofwan, 1977). Jaminan suatu kredit berhubungan dengan bidang hukum benda dan perbankan. Dibidang perbankan kaitan ini terletak pada fungsi perbankan yakni penghimpun dan penyalur dana bagi masyarakat, yang salah satu usahanya adalah memberikan kredit. Kredit merupakan faktor pendukung bagi pembangunan ekonomi. Ini berarti perkreditan mempunyai arti penting dalam berbagai aspek pembangunan, seperti perdagangan, perindustrian, perumahan, transportasi, dan sebagainya (Kamelo, 2004). Persaingan dalam dunia bisnis menjadi salah satu alasan bagi pemilik modal untuk memberikan fasilitas kredit kepada para nasabah. Hal ini dapat dilihat dengan semakin banyaknya timbul lembaga-lembaga jaminan, khususnya untuk jaminan fidusia.

Jaminan merupakan kebutuhan kreditur untuk memperkecil risiko apabila debitur tidak mampu menyelesaikan segala kewajiban yang berkenaan dengan kredit yang telah dikucurkan (Harun, 2010). Pada umumnya dalam rangka mengamankan 
pemberian kreditnya, bank menuntut nasabah debitur untuk memberikan jaminan kebendaan (agunan). Jaminan kebendaan (agunan) pemberian kredit bank tersebut pada hakikatnya berfungsi untuk menjamin kepastian akan pelunasan utang debitur bila debitur cedera janji atau dinyatakan pailit (Usman, 2008). Dengan adanya jaminan, apabila debitur tidak mampu membayar hutangnya maka kreditur dapat memaksakan penggantian atas kredit yang telah diberikan dengan cara menguasai jaminan yang diberikan oleh debitur. Dengan kata lain, jaminan ini bertujuan untuk memberikan perlindungan bagi kreditur apabila terjadi wanprestasi atau cidera janji yaitu suatu keadaan dimana seseorang tidak memenuhi kewajibannya yang didasarkan pada suatu perjanjian atau kontrak. Wanprestasi dapat berarti tidak memenuhi prestasi sama sekali, atau terlambat memenuhi prestasi, atau memenuhi prestasi secara tidak baik.

Secara umum, dikenal dua bentuk jaminan di Indonesia yaitu jaminan perorangan dan jaminan kebendaan. Jaminan yang paling di sukai bank adalah jaminan kebendaan, karena jaminan kebendaan ini mempunyai suatu objek yang pasti dan lansung dapat dinilai secara materil. Salah satu jenis jaminan kebendaan yang dikenal dalam hukum positif adalah jaminan fidusia. Kebendaan yang dijadikan jaminan untuk pelunasan hutang itupun tidak dibatasi macam maupun bentuknya. Kebendaan tersebut haruslah mempunyai nilai secara "ekonomis" serta mempunyai sifat "mudah dialihkan" atau mudah diperdagangkan, sehingga kebendaan tersebut tidak akan menjadikan suatu "beban" bagi kreditur untuk "menjual lelang" pada waktunya, yaitu pada saat mana debitur secara jelas telah melalaikan kewajibannya, sesuai dengan ketentuan dan syarat-syarat yang berlaku dalam perjanjian pokok yang melahirkan utang piutang tersebut (Yani, 2000).

Jaminan fidusia telah digunakan di Indonesia sejak zaman penjajahan Belanda, sebagai suatu bentuk jaminan yang lahir dari yurisprudensi. Bentuk jaminan ini digunakan secara luas dalam transaksi pinjam meminjam, karena proses pembenahannya dianggap sederhana, mudah, dan cepat, tetapi tidak menjamin adanya kepastian hukum. Dalam perjanjian dengan jaminan fidusia ini, baik penerima fidusia maupun pemberi fidusia menurut undang-undang jaminan fidusia sudah sama-sama diberikan perlindungan hukum, bagi pemberi fidusia mendapat perlindungan berupa adanya hak pakai atas benda jaminan, dan apabila terjadi wanprestasi maka tidak akan menyebabkan benda jaminan berubah hak kepemilikannya. Undang-undang Jaminan Fidusia Nomor 42 Tahun 1999 memberikan hak preferen atas piutangnya yaitu hak istimewa bagi penagih (orang yang berpiutang) dan berlakunya asas droit de suite atas benda jaminan yaitu seseorang yang berhak terhadap benda itu, mempunyai kekuasaan atau wewenang untuk mempertahankan atau menggugat bendanya dari tangan siapapun juga atau dimanapun benda itu berada, sedangkan bagi pihak ketiga asas publisitas dalam perjanjian jaminan fidusia akan memberikan informasi terhadap benda-benda yang difidusiakan (Sobirin, 2008).

Memberikan suatu barang dalam jaminan, berarti melepaskan sebagian kekuasaan atas barang itu. Pada asasnya yang harus dilepaskan itu adalah kekuasaan untuk memindahkan hak milik atas barang itu dengan cara apapun juga (menjual, menukarkan, menghibahkan) (Subekti, 1982). Apabila dikemudian hari terjadi wanprestasi oleh debitur, maka kreditur berhak melakukan eksekusi terhadap objek yang difidusiakan seerti yang telah diamanatkan oleh Pasal 1237 Kitab Undangundang Hukum Perdata yang berbunyi: "Pada suatu perikatan untuk memberikan barang tertentu, barang itu menjadi tanggungan kreditur sejak perikatan lahir. Jika debitur lalai untuk menyerahkan barang yang bersangkutan, maka barang itu semenjak 
perikatan itu dilakukan, menjadi tanggungannya". Sebelum mengkaji lebih lanjut tentang fidusia ini, tentunya kita harus terlebih dahulu mengetahui asal mula fidusia itu sendiri. Istilah fidusia barasal dari bahasa belanda, yaitu fiducie dan dalam bahasa Inggris disebut fiduciary transfer of ownership, yang artinya kepercayaan. Dalam berbagai literatur, fidusia lazim disebut dengan istilah fiduciare eigendom overdract (FEO) yaitu penyerahan hak milik berdasarkan kepercayaan. Selanjutnya dalam bahasa belanda disebut juga dengan zekerheids eigendom artinya hak milik sebagai kepercayaan (Wahyudi. 2014).

Fidusia, menurut asal katanya berasal dari kata "fides" yang berarti kepercayaan. Sesuai dengan arti kata, maka hubungan hukum antara debitur (pemberi fidusia) dan kreditur (penerima fidusia) merupakan hubungan hukum yang berdasarkan kepercayaan. Pemberi fidusia percaya bahwa penerima fidusia mau mengembalikan hak milik barang yang telah diserahkan, setelah dilunasi utangnya. Sebaliknya penerima fidusia percaya bahwa pemberi fidusia tidak akan menyalahgunakan barang jaminan yang berada dalam kekuasaannya. Menurut Mahadi "fidusia" berasal dari bahasa latin yang artinya kepercayaan terhadap seseorang atau sesuatu, pengharapan yang besar, juga ada kata "fido" yangmerupakan kata kerja yang berarti mempercayai seseorang atau sesuatu (Mahadi, 1981). Subekti (1982) menjelaskan arti kata "fiduciair" adalah kepercayaan yang diberikan secara timbal balik oleh satu pihak kepada yang lain, bahwa apa yang keluar ditampakkan sebagai pemindahan milik, hanya suatu jaminan saja untuk suatu utang.

Dalam literatur lainnya, fidusia adalah suatu istilah yang berasal dari hukum romawi, yang memiliki dua pengertian yakni sebagai kata kerja dan kata sifat. Sebagai kata benda, istilah fidusia mempunyai arti seorang yang diberi amanah untuk mengurus kepentingan pihak ketiga dengan itikad baik, penuh ketelitian, bersikap hatihati dan berterus terang. Orang yang diberi kepercayaan dibebani kewajiban melakukan perbuatan untuk kemanfaatan orang lain. Sebagai kata sifat istilah fidusia menunjukkan pengertian tentang hal yang berhubungan dengan kepercayaan (trust). Di dalam Pasal 1 angka (1) Undang-undang Nomor 42 Tahun 1999 Tentang Jaminan Fidusia dijumpai, pengertian fidusia yaitu pengalihan hak kepemilikan suatu benda atas dasar kepercayaan dengan ketentuan bahwa benda yang hak kepemilikannya dialihkan tersebut tetap dalam penguasaan pemilik benda. Pengertian pengalihan hak kepemilikan adalah pemindahan hak kepemilikan dari pemberi fidusia kepada penerima fidusia atas dasar kepercayaan, dengan syarat bahwa benda yang menjadi objeknya tetap berada di tangan pemberi fidusia. Jadi fidusia itu merupakan suatu cara pemindahan hak milik dari (debitur) berdasarkan adanya perjanjian pokok (perjanjian utang piutang) kepada kreditur, tetapi yang diserahkan hanya haknya saja secara yuridis levering dan hanya dimiliki oleh kreditur secara kepercayaan saja (sebagai jaminan utang debitur), barangnya tetap dikuasai oleh debitur.

Keluarnya Peraturan Menteri Keuangan Republik Indonesia No.130/PMK.010/2012 ini, tidak serta merta menyempurnakan harapan kita untuk bisa mewujudkan dunia penjaminan lebih baik. Ternyata masih ada kendala lain yang harus kita atasi bersama. Sejalan dengan keluarnya PMKRI No.130/PMK.010/2012 ini, mulai tanggal 5 Maret 2013 telah diberlakukan fidusia on-line, yaitu pendaftaran jaminan fidusia secara on-line oleh Kementerian Hukum dan HAM RI. Satu sisi dengan keberadaaan fidusia on-line ini memang dapat menciptakan kemudahan dalam pendaftaran jaminan fidusia dengan program fidusia on line. Apabila dilihat di sisi lain ada hal-hal yang perlu dikaji secara yuridis agar akta jaminan fidusia yang dibuat oleh 
notaris dapat dipertanggungjawabkan sebagai alat bukti yang kuat dan sertifikat jaminan fidusia mempunyai kekuatan eksekutorial.

\section{B. Metodologi Penelitian}

Metodologi merupakan suatu cara untuk menemukan jawaban akan sesuatu hal. Cara menemukan jawaban tersebut sudah tersusun dalam langkah-langkah tertentu yang sistematis (Soekamto, 2003). Cara dan langkah-langkah yang dilakukan guna mendapatkan data yang konkrit sebagai bahan dalam penelitian ini, agar tulisan ini dapat dipertanggungjawabkan secara ilmiah. Berdasarkan perumusan masalah dan tujuan penelitian, pendekatan masalah yang penulis gunakan dalam penelitian ini didasarkan pada penelitian hukum yang dilakukan dengan pendekatan yuridis empiris, yaitu penelitian terhadap identifikasi hukum (hukum tidak tertulis) (Ali, 2009). Pendekatan yuridis empiris, merupakan suatu pendekatan yang dilakukan untuk menganalisis tentang sejauhmanakah suatu peraturan/ perundang-undangan atau hukum yang sedang berlakusecara efektif, dalam hal ini pendekatan tersebut digunakan untuk menganalisis secara kualitatif tentang pelaksanaan perjanjian kredit yang diikat dengan jaminan fidusia (Soekamto, 1982). Pendekatan empiris ini dimaksudkan sebagai usaha mendekati masalah yang diteliti dengan sifat hukum yang nyata atau sesuai dengan kenyataan yang hidup dalam masyarakat. Pada penelitian hukum empiris, yang diteliti pada awalnya adalah data sekunder, untuk kemudian dilanjutkan dengan penelitian terhadap data primer dilapangan, atau terhadap masyarakat. Sifat penelitiannya dengan metode penelitian deskriptif yaitu menggungkapkan peraturan perundangundangan yang berkaitan dengan teori-teori hukum yang menjadi objek penelitian.

\section{Hasil dan Pembahsan}

Berdasarkan hasil penelitian, proses penjaminan dengan jaminan fidusia pada BPR Dharma Nagari Koto baru, sama dengan proses penjaminan fidusia pada umumnya, yaitu proses pengikatan perjanjian kredit sebagai perjanjian pokok, dan pengikatan fidusia sebagai perjanjian accesoir. Dalam setiap memberikan kredit kepada nasabahnya bank selalu menghadapi suatu resiko yaitu tidak kembalinya uang yang dipinjamkan pada nasabah. Oleh karena itu keadaan nasabah harus diikuti terus menerus mulai pada saat kredit diberikan sampai kredit lunas. Mengingat resiko tidak kembalinya uang dan kemungkinan objek jaminan dijual pada pihak ketiga, maka setiap Perjanjian Kredit harus disertai jaminan yang cukup dan telah diikat berdasarkan undang-undang yang berlaku. Salah satu wujud dari pemberian kepastian hukum hakhak kreditur adalah dengan adanya lembaga pendaftaran fidusia yaitu kantor pendaftaran fidusia.

Dalam pelaksanaannya telah melakukan pendaftaran terhadap jaminan fidusia. Walaupun telah melaksanakan ketentuan dalam UUJF dengan baik dan telah melakukan pendaftaran terhadap jaminan fidusia tetapi BPR Dharma Nagari Koto Baru masih memiliki pengecualian yaitu perjanjian kredit yang memiliki nominal kecil (tidak disebutkan angkanya) tidak didaftarkan. Hal ini dikarenakan faktor keuntungan yang sangat rendah dan faktor resiko dari perjanjian tersebut yang tidak terlalu besar. Sebagaimana dalam Undang-undang Jaminan Fidusia Nomor 42 Tahun 1999 pelaksanaan perjanjian kredit dengan jaminan fidusia ini tidak memberikan sanksi yang tegas terhadap para pelaku fidusia yang tidak mendaftarkan jaminan fidusia walaupun dalam pasal 11 UUJF tersebut terdapat kewajiban terhadap para pelaku fidusia untuk mendaftarkan jaminan fidusia. Selanjutnya memang pada Pasal 
36 UUJF diatur tentang perlindungan terhadap penerima fidusia atau kreditur apabila terjadi wanprestasi.

Pengaturan terhadap perlindungan kreditur itu tidak serta merta dapat mengikat pihak debitur karena banyak celah dari undang-undang tersebut yang dapat membuat para pihak berkelit dan ingkar janji. Undang-undang Republik Indonesia Nomor 42 Tahun 1999 tentang Jaminan Fidusia ini, mengatur mengenai tata cara pendaftaran jaminan fidusia, namun tidak sampai mengatur tentang prosedural dan proses pendaftaran, sehingga tidak ada kewajiban pendaftaran tersebut bagi jaminan fidusia. Ketidakadaan kewajiban pendaftaran tersebut sangat dirasakan dalam praktek sebagai kekurangan dan kelemahan bagi pranata hukum fidusia. Selain menimbulkan ketidakpastian hukum, absennya kewajiban pendaftaran jaminan fidusia tersebut menyebabkan jaminan fidusia tidak memenuhi unsur publisitas, sehingga susah dikontrol. Hal ini dapat menimbulkan hal-hal yang tidak sehat dalam praktek, seperti adanya fidusia dua kali tanpa sepengetahuan krediturnya, adanya pengalihan barang fidusia tanpa sepengetahuan kreditur, dan lain-lain.

Pendaftaran jaminan fidusia merupakan salah satu wujud dari asas publisitas. Dengan pendaftaran, diharapkan agar pihak debitur terutama yang tidak beritikad baik, tidak lagi dapat memfidusiakan sekali lagi atau bahkan menjual ataupun mengalihkan objek jaminan fidusia kepihak ketiga tanpa sepengetahuan kreditur. Fidusia wajib didaftarkan di kantor pendaftaran fidusia, untuk pertama kali kantor pendaftaran fidusia didirikan di Jakarta, kemudian secara bertahap, sesuai keperluan, didirikan di ibukota propinsi di seluruh wilayah Indonesia, dan dapat juga didirikan di setiap daerah tingkat II yang harus dapat disesuaikan dengan Undang-undang Republik Indonesia Nomor 22 Tahun 1999 tentang Pemerintahan Daerah. Sesuai dengan Keputusan Presiden Republik Indonesia Nomor 139 Tahun 2000 jo. Keputusan Menteri Hukum dan Hak Asasi Manusia Republik Indonesia Nomor M.03.PR.07.10 Tahun 2001 jo. Keputusan Menteri Hukum dan Hak Asasi Manusia Republik Indonesia Nomor M.02.PR.07.10 Tahun 2002. Sejak tanggal 1 April 2001 Kantor Pendaftaran Fidusia Direktorat Jenderal Administrasi Hukum Umum sudah tidak lagi melakukan Pendaftaran Sertifikat Jaminan Fidusia dan pendaftaran dilaksanakan di kantor pendaftaran fidusia pada Kantor Wilayah Departemen Hukum dan Hak Asasi Manusia Republik Indonesia di tempat kedudukan pemberi fidusia.

Karena banyaknya celah dalam undang-undang ini maka sebagian besar bank ataupun lembaga pembiayaan merasa tidak mempunyai kewajiban untuk mendaftarkan fidusia, namun ketika bank ataupun lembaga pembiayaan tersebut merasa debitur mulai tidak memenuhi kewajibannya, maka disaat itulah mereka baru mendaftarkan fidusia tersebut. Sehingga dapat dipastikan tingkat kepatuhan masyarakat dalam menjalankan undang-undang jaminan fidusia ini masih sangat rendah. Bagi para nasabah atau debitur, yang mereka ketahui adalah untuk mendapatkan pinjaman mereka harus memberikan agunan yang nilainya harus melebihi jumlah pinjaman mereka. Perbedaan mengenai jenis agunan pun tidak dipahami oleh debitur, agunan berupa benda bergerak ataupun benda tidak bergerak tidak menjadi patokan bagi mereka untuk mendapatkan pinjaman. Berpindahnya kepemilikan dari agunan tersebut juga tidak dipahami, karena bagi mereka untuk agunan benda bergerak, benda tersebut tetap menjadi milik mereka. Hanya saja bila mereka tidak mampu melunasi hutanghutangnya barulah benda bergerak tersebut berpindah tangan.

Sejalan dengan semakin mendesaknya kebutuhan masyarakat tentang pengaturan hukum tentang fidusia, pada tanggal 7 Agustus 2012 keluar Peraturan Menteri Keuangan Republik Indonesia Nomor 130/PMK.010/2012 tentang Pendaftaran 
Jaminan Fidusia bagi perusahaan pembiayaan yang melakukan pembiayaan konsumen untuk kendaraan bermotor dengan pembebanan jaminan fidusia. Peraturan ini diharapkan dapat membuat pendaftaran fidusia ini mulai menjadi lebih tertib. Sehubungan dengan adanya penertiban ini, bank-bank yang bergerak di bidang pembiayaan ataupun lembaga-lembaga pembiayaan lainnyapun mulai membenahi pelaksanaan perjanjian kredit dengan jaminan fidusia. Kewajiban melakukan pendaftaran mulai dilaksanakan sesuai dengan ketentuan Peraturan Menteri Keuangan Republik Indonesia Nomor 130/PMK.010/2012.

Dengan keluarnya peraturan ini bank tersebut menjadi lebih selektif dan lebih disiplin terhadap nasabahnya. Sejauh ini walaupun BPR Dharma Nagari telah lebih disiplin dengan melaksanakan pendaftaran jaminan fidusia, namun masih tetap memiliki pengecualian yaitu perjanjian kredit yang hanya memiliki nominal $\mathrm{Rp}$. 2.000.000,-(dua juta rupiah) kebawah tidak didaftarkan dengan alasan karena nilai kredit yang sangat rendah dan faktor resiko yang sangat rendah pula. Disamping itu, persaingan bisnis antara sesama bank juga menjadi salah satu faktor tidak didaftarkannya jaminan fidusia tersebut, karena dengan didaftarkan maka akan menambah beban bagi si debitur, sedangkan jumlah pinjamannya sangat kecil. Jadi antar sesama bank juga berlomba agar bisa mendapatkan lebih banyak lagi nasabah dengan berusaha meminimumkan beban nasabahnya.

Pihak BPR Dharma Nagari Koto Baru menyadari bahwa setelah ditelaah lebih jauh Peraturan Menteri Keuangan Republik Indonesia Nomor 130/PMK.010/2012 tentang Pendaftaran Jaminan Fidusia ini, ternyata memiliki beberapa penekanan yaitu: a) Ketentuan wajib mendaftarkan jaminan fidusia di kantor pendaftaran fidusia; b) Menegaskan jangka waktu pendaftaran merupakan langkah untuk menjamin kepastian hukum; c) Menekan tindakan yang bertentangan dengan rasa keadilan dengan mengatur masalah tata cara penarikan benda jaminan fidusia; d) Penerapan sanksi yang tegas terhadap pelanggaran ketentuan tersebut sangat diperlukan sebagai upaya paksa juga untuk pelaksanaan pendaftaran obyek jaminan fidusia; dan e) Lebih memberikan rasa keadilan karena dengan dilaksana kan pendaftaran obyek jaminan fidusia, maka apabila debitur wanprestasi akan ditempuh cara-cara eksekusi sesuai UU No.42 Tahun 1999.

Menurut penulis dengan mengeluarkan Peraturan Menteri Keuangan Republik Indonesia Nomor 130/PMK.010/2012 tentang Pendaftaran Jaminan Fidusia tidak serta merta dapat menjawab permasalahan yang ada, sebaliknya menimbulkan masalah baru diantaranya dengan pendaftaran online tidak memenuhi ketentuan pendaftaran pada kantor pendaftaran fidusia, dan tidak diroyanya jaminan fidusia yang didaftarkan tersebut dapat menyebabkan debitur melakukan fidusia ulang. Untuk menertibkan semua permasalahan yang timbul dalam perjanjian dengan jaminan fidusia ini, penulis merasa pemerintah perlu membedah dan memikirkan lagi suatu aturan yang dapat mengikat secara tegas baik itu pihak debitur maupun pihak kreditur. Amandemen terhadap Undang-undang yang telah ada sangatlah diperlukan, sehingga dengan adanya undang-undang yang mengatur kewajiban pendaftaran jaminan fidusia disertai sanksi yang tegas, pelaksanaannya, ataupun mengenai roya terhadap pendaftaran jaminan fidusia tersebut yang dapat menutup celah bagi kreditur dan debitur untuk tidak taat hukum.

Terlepas dari semua upaya penyelamatan kredit, baik itikad baik yang dilakukan oleh debitur, ataupun upaya-upaya lain yang dilakukan oleh kreditur untuk mengembalikan hak-hak yang akan diterima yang telah diperjanjikan sebelumnya. Faktor pendaftaran jaminan fidusia menjadi hal yang sangat penting dan harus 
dilakukan. Karena dengan tidak didaftarkannya jaminan fidusia tersebut, maka tidak adanya kekuatan hukum yang mengikat untuk mengeksekusi jaminan yang sudah diagunkan. Jaminan yang didaftarkan, apabila terjadi wanprestasi dapat dieksekusi melalui pelelangan umum atas dasar pelaksanaan titel eksekutorial yang sama dengan putusan pengadilan yangberkekuatan hukum tetap. Bank (penerima fidusia) dapatlangsung melaksanakan eksekusi melalui pelelangan umum (lewat pejabat lelang swasta) atas objek jaminan fidusia.

Sertifikat Jaminan Fidusia mempunyai kekuatan eksekutorial sama seperti putusan pengadilan yang telah memperoleh kekuatan hukum tetap, namun Sertifikat Jaminan Fidusia bukan merupakan atau pengganti dari putusan pengadilan, yang jelas, walaupun bukan putusan pengadilan, karena Sertifikat Jaminan Fidusia mempunyai kekuatan eksekutorial yang "sama" dengan putusan pengadilan yang telah memperoleh kekuatan hukum tetap maka pelaksanaan eksekusi objek Jaminan Fidusia berdasarkan grosse Sertifikat Jaminan Fidusia atau dengantitel eksekutorial Sertifikat Jaminan Fidusia mengikuti pelaksanaan suatu putusan pengadilan. Dalam Sertifikat Jaminan Fidusia, karena dibubuh dengan irah-irah dengan kata-kata "Demi Keadilan Berdasarkan Ketuhanan Yang Maha Esa", mempunyai kekuatan eksekutorial. Sertifikat Jaminan Fidusia tersebut dengan sendirinya dapat dieksekusi tanpa menunggu flat eksekusidari pengadilan, sebab kekuatannya sama dengan sebuah putusan pengadilan yang telah memperoleh kekuatan hukum yang tetap. Atas dasar ini, penerima fidusia dengan sendirinya dapat mengeksekusi benda yang dijadikan sebagai objek Jaminan Fidusia jika debitor atau pemberi fidusia cidera janji, tanpa harus menunggu adanya surat perintah (putusan) dari pengadilan. Akibat tidak didaftarkannya jaminan fidusia ini memang hanya akan dirasakan oleh kreditur, karena haknya untuk memiliki atau mengeksekusi jaminan fidusia tidak mempunyai kekuatan hukum. Namun sejauh ini kreditur masih belum jera untuk tidak mendaftarkan jaminan fidusia tersebut dengan beragam alasan.

\section{Penutup}

Pelaksanaan perjanjian jaminan fidusia belum sepenuhnya sejalan, belum sepenuhnya memenuhi ketentuan tentang jaminan fidusia terutama dalam hal pendaftaran jaminan fidusia. Mengenai pendaftaran jaminan fidusia, memiliki pengecualian yaitu untuk nominal perjanjian kredit yang sangat kecil yaitu dibawah 2.000.000,- (dua juta rupiah) perjanjian dibuat dengan perjanjian dibawah tangan dan adanya legalisasi notaris namun hanya sebatas itu, tanpa ada proses pendaftaran. Faktor yang mempengaruhi tidak dilaksanakannya pendaftaran jaminan fidusia ini karena menurut pihak bank nominal kredit yang sangat rendah sehingga resiko dari kerugiannya juga sangat kecil. Disamping itu, persaingan bisnis antara sesama bank juga menjadi salah satu faktor tidak didaftarkannya jaminan fidusia tersebut, karena dengan didaftarkan maka akan menambah beban bagi si debitur, sedangkan jumlah pinjamannya sangat kecil. Jadi antar sesama bank juga berlomba agar bisa mendapatkan lebih banyak lagi nasabah dengan berusaha meminimumkan beban nasabahnya.

\section{Daftar Pustaka}

Atik Catur Budiati, Sosiologi Konstektual, CV Mediatama, Jakarta, 2009.

Bambang Sutiyoso, Aktualita Hukum dalam Era Reformasi, PT. Raja Grafindo Persada, Jakarta, 2004. 
Badriyah Harun, Penyelesaian Kredit Bermasalah, Cetakan Pertama, Pustaka Yustisia, Yogyakarta, 2010.

Departemen Pendidikan Nasional, Kamus Besar Bahasa Indonesia Pusat Bahasa, Edisi Keempat, PT. Gramedia Pustaka Utama, Jakarta, 2008.

Gunawan Widjaya dan Ahmad Yani, Seri Hukum Bisnis Jaminan Fidusia, Jakarta, 2000 .

Mariam Darus Badrulzaman, Mencari Sistem Hukum Benda Nasional, Alumni, Bandung, 1983.

Mahadi, Hak Milik dalam Hukum Perdata Nasional, Proyek BPHN, 1981.

Peter Mahmud Marzuki, Penelitian Hukum, Kencana Press, Jakarta, 2009.

Rachmadi Usman, Hukum Jaminan Keperdataan, Sinar Grafika, Jakarta, 2008.

R. Subekti, Jaminan-Jaminan untuk Pemberian Kredit Menurut Hukum Indonesia, Alumni, Bandung, 1982.

Sri Soedewi Masjchoen Sofwan, Beberapa Masalah Pelaksanaan Lembaga Jaminan Khususnya Fidusia di Dalam Praktek dan Perkembangannya di Indonesia, Fakultas Hukum Universitas Gadjah Mada, Yogyakarta, 1977.

Salim Hs, Perkembangan Hukum Jaminan di Indonesia, PT. Raja Grafindo Persada, Jakarta, 2004.

Soerjono Soekamto dan Sri Mamudji, Penelitian Hukum Normatif Suatu Tujuan Singkat, Cetakan 14, Rajawali Pers, jakarta, 2012.

Satjipto Rahardjo, Hukum dan Masyarakat, Angkasa, Bandung, 1984.

Sudikno Mertokusumo, Hukum Acara Perdata Indonesia, Liberty, Jogyakarta, 1993.

Tan Kamelo, Hukum Jaminan Fidusia Suatu Kebutuhan Yang Didambakan, Alumni, Bandung, 2004im, Teori damn Metodologi Penelitian Hukum Normatif, Cetakan Kedua.

Bayu Media Publishing, Jawa Timur, 2006.

Tjipto Adinugroho, Perbankan Masalah Perkreditan, Seri I,Pradnya Paramita Jakarta, 1994.

Zainuddin Ali, Metode Penelitian Hukum, Cetakan Pertama, Sinar Grafika, Jakarta, 2009

Zainal Asikin, Pengantar Ilmu Hukum, PT. Raja Grafindo Persada, Jakarta, 2012. 